\title{
DETERMINING THE AERODYNAMIC CHARACTERISTICS OF A PROPELLER-DRIVEN ANTI-UAV FIGHTER WHILE DESIGNING AIR PROPELLERS
}

\author{
Vasyl Loginov $^{*_{1}}$ (D) 0000-0003-4915-7407 \\ Yevgen Ukrainets $^{2}$ (D) 0000-0002-7674-0588 \\ Viktor Popov ${ }^{1}$ (D) 0000-0001-9189-6882 \\ Yevgen Spirkin ${ }^{2}$ (DD 0000-0003-2924-0545 \\ ${ }^{1}$ JSC FED, 132 Sumska Str., Kharkiv, 61023, Ukraine \\ ${ }^{2}$ Ivan Kozhedub Kharkiv National Air Force University, 77/79 Sumska Str., Kharkiv, 61023, Ukraine \\ *login_w@ukr.net
}

\begin{abstract}
Given the rising importance of unmanned aerial vehicles (UAVs), this article addresses the urgent scientific problem of determining the aerodynamic characteristics of a UAV while laying out the propellers for the wings. We discuss the methodology for experimental wind-tunnel studies of aircraft configurations with propellers. It is shown that a characteristic feature of the configuration small-elongation wing with propellers is the absence of elements that are not affected by propellers. This feature makes it difficult to implement and automate a wind tunnel experiment, since there are problems with providing similar criteria for a working propeller; it is difficult to achieve perfect balancing for solid drive propellers, which causes vibration, the level of which depends on uncontrolled factors; the inability to neglect the presence of the body elements influence to the blades of propellers; the difficulty of direct measuring propeller thrust and torque. The presented methodology involves the integrated usage of experimental and numerical methods to eliminate the difficulties in conducting physical experiments in a wind tunnel. This approach makes it possible to combine the high credibility of experimental data in the study of the physical essence of phenomena with high efficiency and accuracy in determining aerodynamic characteristics by numerical methods. Using this approach, we established dependences of the aerodynamic characteristics of the small-elongation wing configuration with counter-rotating propellers on the geometric and kinematic parameters of the configuration for other extensions and constrictions of the wings. These data can serve as the basis for the development of recommendations for the selection of sensible geometric parameters of the aerodynamic configuration of a small-elongation wing with counterrotating propellers.
\end{abstract}

Keywords: unmanned aerial vehicle, fighter, aerodynamic characteristics, aerodynamic configuration, propeller, propeller regulator

Type of the work: Research Article 


\section{INTRODUCTION}

An important direction of development in aviation technology - including in the aerospace industry of today's Ukraine - consists in is the design, development and production of unmanned aerial vehicles (UAVs). Modern UAVs are relatively cheap, have a modular design, small dimensions, a small effective dispersion surface and lower vulnerability to enemy air defense as compared to manned aircraft, which enables them to serve as effective means of reconnaissance, guidance and electronic warfare. Progress in the miniaturization of airborne hardware has given rise to the creation of small-sized aircraft known as micro-UAVs. The main advantages of micro-UAVs are as follows: a reduced level of visibility; increased mobility (due to small dimensions and weights) in conjunction with a high degree of combat effectiveness; potential wide-scale use with a high frequency of flights; reduced requirements in terms of staff numbers and level of qualification; and significant cost reduction due to automation of production processes in the manufacture of structures from various materials. UAVs widely employ propeller drives, powered by piston and turboprop engines.

This gives rise to a need for new power plants of these types based on innovative technologies, with the supply of parts and components also playing an important role. To address the most urgent, largescale and important scientific and technical problems for Ukraine in recent years, a set of innovative technologies for surface treatment of parts and products for the defense and energy sectors of Ukraine has been created, scientifically developed, improved and introduced into production. At the JSC "FED" plant in Kharkiv, a method has been introduced for ion-plasma precision nitriding of the surfaces of steels parts and alloys, AVINIT N $[1,2,3]$. The application of this innovative approach provides for a more meaningful discussion of the surface treatment method for elements of an automatic propeller regulator. However, this approach requires the aerodynamic characteristics of the propeller to be determined in order to determine the range of parameters and characteristics of the automatic propeller regulator for its further improvement.

\section{LITERATURE REVIEW AND PROBLEM STATEMENT}

Analysis of UAV usage for various purposes points to the need to develop fighters with the main task of combating other small UAVs in the air [4]. Success in solving the problem of destroying other small UAVs in the air depends on the choice of the aerodynamic configuration of the UAV fighter. The most important requirements that determine the aerodynamic configuration of such a UAV fighter will be to ensure: high constant overloads and high lift values to ensure superiority over reconnaissance and strike UAVs (RS UAVs) in maneuverable aerial combat; low resistance for velocity advantages over RS UAV; high maximum lift for best takeoff and landing performance. The requirements for the aerodynamic configuration of a UAV fighter are contradictory, which necessitates the use of configuration solutions for deep integration of the airframe and power plant. One example of such solutions involves the usage of small-elongation wings as the supporting surface of the aircraft, which, in combination with propellers located on the wing lateral edges, allows for high values of the takeoff and landing characteristics of the aircraft to be obtained, making it possible to carry out steady horizontal flight at extremely small (close to evolutive) velocities and increases the maximum velocity of horizontal flight.

The aerodynamic configuration of a UAV fighter as described above has several advantages over the traditional configuration, with wings of moderate and large elongations. However, the interference features of such a configuration have not been fully studied; therefore, identifying the pattern of interference of a small-elongation wing assembly with counter-rotating propellers on the lateral wing edges is relevant to ensure an advantage in the flight performance of a UAV fighter over RS UAV. In addition, the automatic propeller must not allow significant deviations in revolutions from those set when the rotor load changes, as it is especially dangerous to exceed the preset number of revolutions. The stability of the number of 
revolutions grows greater, the faster the angle of installation of the blades changes, which in turn depends on the data of the regulator, on the moments acting on the blades of the propeller. Therefore, when designing regulatory systems, it is necessary to be guided by the requirements in the aerodynamics of air propellers during the aircraft configuration.

Existing UAV designs are quite unevenly categorized [4]. Analysis of the data presented shows that the largest group consists of small UAVs, i.e. micro UAVs (with a maximum flight weight of up to $5 \mathrm{~kg}$ ), mini UAVs (up to $200 \mathrm{~kg}$ ), as well as short, medium range UAVs with maximum flight weight up to $10 \mathrm{~kg}$. This is due to the relative ease of use and accessibility, suitability for various tasks [5]. The most numerous UAVs have the following main flight characteristics:

- flight duration - 60-120 minutes;

- radius of action $-10-15 \mathrm{~km}$

- maximum take-off weight $-1.5-6.5 \mathrm{~kg}$

- maximum flight velocity $-80-120 \mathrm{~km} / \mathrm{h}$.

It may thus be concluded that UAV s of this type will be typical targets for a UAV fighter. As the task is to synthesize the aerodynamic configuration of a such fighter, such a solution calls for:

- analysis of ways to improve the flight performance of a fighter using a small-elongation wing configuration with counter-rotating propellers;

- development and verification of a theoretical and experimental methodology for determining the basic aerodynamic characteristics of a low-wing wing assembly with counter-rotating propellers located on the side edges;

- parametric studies of the influence of the geometric and kinematic parameters of the configuration on its aerodynamic characteristics, revealing features of the flow around the small-elongation wing configuration with counter-rotating propellers;

- identification the patterns of change in the aerodynamic characteristics of the small-elongation wing configuration with counter-rotating propellers when changing the operating modes of air propellers, kinematic flow parameters, and geometric parameters of the wing;

- development of practical recommendations for designers on the application of the smallelongation wing configuration with counter-rotating propellers on UAV fighters.

The key point among the above listed tasks is the development of a reliable theoretical and experimental methodology for determining the basic aerodynamic characteristics of complex spatial aerodynamic configurations with propellers. Propeller interference with an airframe has been, and indeed remains, one of the most important problems in the development of aerodynamic configurations of aircraft. The widespread usage of propellers in small-sized aircraft is due to the high efficiency of the propeller as a propulsion device; however, the effective thrust of a propeller-driven power plant significantly depends on the propeller's location on the aircraft. A small-elongation wing, in cooperation with counter-rotating propellers on the wing lateral edges, has the greatest possible interference effect, therefore, analysis of previous studies of the aerodynamic interference of a propeller with elements of an airframe is also relevant.

The first study of the aerodynamic interference of a propeller with a three-dimensional body was carried out by Rankin [6], who experimentally studied the ratio of propeller thrust and hull resistance both above an insulated propeller and hull, and as part of a propeller-body combination. Experimental studies of motor nacelles with a working propeller (Durand, Feige, Collins, Lesley, Vedrov, Ostoslavsky, Khalezov) made it possible to quantify the mutual influence of the nacelle and propeller [7]. The obtained empirical materials served as the basis for the semi-empirical theory of interference (Glauert, Ostoslavsky). Configuration optimization of the power plant on an airplane is considered in [8-11]. It should be noted that aerodynamic interference between the propeller and the airframe also affects the stability and controllability characteristics of aircraft with propeller engines. 
In Ukraine, similar studies have been presented in [12-14]. Experimental studies of the problem of interference of propellers with an airframe are presented in [15], which improved the test procedure for wind models of aircraft with propeller engines in a wind tunnel, established the nomenclature of corrections to the test results, and developed methods for their determination. It was found that the mean-square deviations of the aerodynamic load measurements acting on a model with a working power plant are 1.5 times higher than in ordinary weight tests of a model without a power plant. It was shown that propellers affect the longitudinal stability of the aircraft, while the magnitude of the focus shift along the angle of attack is determined by two dominant components: the effect of the jets on the glider and the moment of normal propeller power. Based on the results of the studies mentioned, it has been concluded that the effect of air propellers on the airframe of an aerodynamic configuration with the placement of propellers on the wing manifests itself in an increase in the aircraft's potential bearing capacity, an increase in drag and a decrease in aerodynamic quality.

Experimental study of the "wing-propeller" aerodynamic combination is much more complicated than the study of the mutual influence of the propeller and the fuselage. In testing a fuselage model with a working propeller, the experiment, as a rule, comes down to measuring the axial forces acting on the propeller and fuselage. In testing the wing-propeller combination model, the difficulty lies in the need to obtain the value of at least three load components acting on the wing, as well as the value of the axial force of the propeller. Simultaneous determination of the increase in drag of the wing, blown by the propeller jet, and propeller thrust is difficult. Thus, the experimental findings obtained in [12-15] do not fully establish the mutual influence of the wing and propeller, especially in the case of small-elongation wings.

It has been shown in [16-20] that small-elongation wings have a number of advantages: they are advantageous in terms of weight, in terms of strength due to small bending moments of the wings, the focus of small elongation-wings shifts relatively little with increasing flight velocity, so the characteristics affect longitudinal stability little. Small-elongation wing aircrafts have small moments of inertia in comparison with traditional configuration aircraft. The internal space of such aircraft allows the payload and crew to be rationally placed. The most significant drawback of small-elongation wings is the large inductive resistance due to significant finite flows on the lateral edges of the wing, and, as a result, low aerodynamic quality.

It has been shown in [19-20] that the final aerodynamic surfaces can improve the aerodynamic quality of an aircraft with a small-elongation wing. The developed rational configuration of an aircraft with a small-elongation wing and end wings, which provides acceptable aerodynamic characteristics and acceptable longitudinal static stability and controllability of the aircraft, and aerodynamic quality is increased by about 3 units compared to a wing without end aerodynamic surfaces.

The interference of a small elongation wing with a propeller is strongly manifested in the "arched wing - pushing propeller” configuration. In famous works by V. Pustovoitov, M. Orlov, M. Mirgazov, V. Siagaev, Ye. Zaitsev, A. Dergachev and A. Davtanian based on the study of arched wings in wind tunnels, important information about the nature of the dependence of the total aerodynamic forces and moments acting on such a wing on the angle of attack and the mutual influence of the arched wing and propeller is studied. It has been shown that the "arched wing - propeller" system has unique aerodynamic features and is an attractive alternative to the straight wing when operational requirements limit the wing span to low values or if the design requires a long flight at low velocities.

In [21-24], on the basis of mathematical and field modeling, features of the nature of the flow over the upper arched wing surface in the "arched wing - pushing propeller" configuration are established, namely: a significant increase in the wing lift force and critical angle of attack due to the influence of inductive flux air in front of the propeller, providing a significant increase in the aerodynamic quality of the configuration compared to the insulated arched wing. Based on the performed parametric studies, the dependences of the aerodynamic quality of the arched wing-pusher propeller assembly and the traction characteristics of the propeller on the propeller location in the wing channel are obtained. 
The original design of a vertical takeoff and landing aircraft with a vertical fuselage configuration was proposed by C. Zimmerman in 1933 and filed in a patent application in 1938. One distinctive feature of its configuration is the usage of small-elongation wings $(\lambda=1)$, almost round in shape, with two large-diameter air propellers, installed with overlapping gondolas at the ends of the wing. The air propellers rotate in opposite directions to the vortices coming from the ends of the wing. Such placement of the propellers is meant to significantly reduce the inductance of the propeller-wing system and as a result obtain an aerodynamic quality of at least 4, allowing, firstly, for high flight velocities to be achieved, and secondly, for the range of horizontal flight velocities to be expanded by reducing the minimum velocity $[25,26]$. It is assumed that such an aircraft would be able to perform vertical take-off and landing, fly in hover mode like a helicopter and at the same time attain a maximum flight velocity of up to $800 \mathrm{~km} / \mathrm{h}$. Landing in autorotation mode with idle engines is possible for a helicopter, but is not allowed for such an aircraft - because of the load on the area covered with propellers being more than in helicopters, and, accordingly, the very high velocity reduction.

A study of propellers carried out by NASA has indicated that a compromise solution could be found: that an "unloaded propeller" could be created, for a relatively high relative efficiency in vertical take-off and landing modes and, at the same time, for high efficiency in horizontal flight $(\eta=0.65-0.85)$ to velocities of $M=0.8$. It was found that in the range of flight velocities from 0 to $400 \mathrm{~km} / \mathrm{h}$, changing the air propellers' rotation velocity is not required, with an increase in velocities from 400 to $640 \mathrm{~km} / \mathrm{h}$, it is desirable, and at velocities of more than $640 \mathrm{~km} / \mathrm{h}$ it is necessary. Horizontal flight control of an aircraft with a power plant must be ensured, as in a conventional aircraft with the help of aerodynamic surfaces, it also requires to take into account, especially when landing, the control surfaces aerodynamic efficiency, because they are located in the stream from the propellers.

After implementing and testing of large-scale models in wind tunnels by the company ChanceVought, a prototype was built in 1941. It was decided to test its aerodynamic design in the wind tunnel of Langley Research Center. The experimental aircraft V-173 began to undergo flight tests in 1942, continuing to 1947 . The limited power of the piston engines installed on the aircraft, even with using large three-blade air propellers with a diameter of $5.03 \mathrm{~m}$, could not provide vertical take-off, but did make it possible to fly at a minimum velocity of only $56 \mathrm{~km} / \mathrm{h}$. With a take-off mass of $1365 \mathrm{~kg}$, the two propellers provided maximum thrust not exceeding $910 \mathrm{~kg}$ and did not provide vertical take-off; therefore, for take-off the aircraft was equipped with a special long main landing gear. Using that landing gear the fuselage had a take-off angle of $40^{\circ}$ to the runway, making it possible to take off with a short takeoff run of only $60 \mathrm{~m}$, and also to land with a very low distance.

During tests in 1942-1947, 210 flights were completed and quite satisfactory handling characteristics were demonstrated at low flight velocities. With a headwind of $46 \mathrm{~km} / \mathrm{h}$, the aircraft could rise vertically; in flights, a velocity of $222 \mathrm{~km} / \mathrm{h}$ was reached at an altitude of $1524 \mathrm{~m}[25,26]$.

In 1943, the US Navy entered a contract with Chance-Vought for the development of an experimental all-metal carrier-based fighter, designated the XF5U-1. The first flight was performed in January 1947, in subsequent flights the velocity record was achieved for that time $-811 \mathrm{~km} / \mathrm{h}$ at an altitude of $8800 \mathrm{~m}$. The possibility of vertical take-off and hovering flight with a reduced take-off weight was also demonstrated.

At the same time, well-known modern publications offer practically no information about the influence of the air propeller operating mode, the wing shape and the relative position of propellers and wing on the aerodynamic characteristics in such a configuration. As such, the interference effect of small-elongation wings with opposing rotor propellers on the lateral wing edges has not been sufficiently studied. Parametric studies of the geometric parameters of the aerodynamic configuration of a small elongation wing in interaction with counter-rotating propellers on the lateral edges have not been carried out. 


\section{THE AIM AND OBJECTIVES OF RESEARCH}

The aim of the article is to establish how patterns of interference influence a UAVs fighter's layout, to determine the aerodynamic characteristics of propellers in a specific configuration so as to provide initial data for the development of a propeller regulator.

\section{METHODS OF RESEARCH}

Numerical implementation of the methodology for determining the aerodynamic characteristics of the small-elongation wing configuration with opposite-rotating propellers requires, at each design calculation step, compliance with the condition of "non-permeability" by swirl segments of the shroud, which descends from the blades of the propeller mover, as well as the panels into which the surface of the nacelle is divided. The position of the vortex sheet behind the wing of small elongation is determined taking into account the non-linearity of its spatial position using the method of discrete vortices (MDV) and the method of perturbed potentials [27]. Experimental studies of the aerodynamic interference of a propeller engine and an airframe are complex.

In the physical modeling of aerodynamic assemblies with propellers, in addition to the requirements for matching Reynolds and Mach numbers, it is necessary to maintain the correspondence of a still dimensionless parameter - the load on the area is tightened by a propeller:

$$
B=\frac{P}{q_{\infty} \cdot F_{p}},
$$

where

$P$ - air propeller thrust;

$q_{\infty}=\frac{\rho_{\infty} \cdot V_{\infty}^{2}}{2}-$ dimensional coefficient of velocity pressure;

$\rho_{\infty}, V_{\infty}-$ density and velocity of unperturbed flow;

$F_{p}=\frac{\pi \cdot d_{p}^{2}}{4}-$ propelled area;

$d_{p}$ - propeller diameter.

When modeling the propeller operation, it is necessary to take into account dimensionless parameters $\bar{\alpha}$ and $\bar{\beta}$, which are found from the ratios:

$$
\begin{aligned}
& P=\bar{\alpha} \cdot \rho \cdot n_{s}^{2} \cdot d_{p}^{4}, \\
& N=\bar{\beta} \cdot n_{s}^{3} \cdot d_{p}^{5},
\end{aligned}
$$

where

$\bar{\alpha}$ - propeller thrust coefficient;

$\bar{\beta}$ - propeller power factor;

$P$ - air propeller thrust;

$N$ - propeller power;

$n_{s}$ - the number of propeller revolutions per second. 
When modeling the propeller operation, it is necessary to satisfy the following requirements:

$$
\bar{\alpha}=\mathrm{idem}, \bar{\beta}=\mathrm{idem},
$$

where $\lambda=\frac{V}{n_{s} \cdot d_{p}}-$ determining velocity coefficient.

The similarity in viscosity and compressibility of air is considered relative to the propeller blades. The correspondence of Reynolds numbers for similar radius $r$ and local chord $b$ cross sections of blades full-scale propeller and its model is presented below:

$$
\omega_{\mathrm{mod} e l}=\omega\left(\frac{r}{r_{\mathrm{mod} e l}}\right)\left(\frac{b}{b_{\mathrm{mod} e l}}\right),
$$

where $\omega=2 \pi \cdot n_{s}$ - the angular frequency of propeller rotation.

When testing models of propellers, the fulfillment of the similarity condition for viscosity and compressibility of air requires large angular frequencies to be created, at which the effect of compressibility of air can no longer be neglected. The need to fulfill the condition for matching Mach numbers creates a significant problem. The complexity of the experimental study of the aerodynamic interference of propeller engines and the airframe is also due to the need to measure the increase in aerodynamic loads on an order of smallness lower than the first, because in the experiment it is necessary to determine not the magnitude of the lift force, the drag force from the airflow, but its increase for different propellers relative to the wing. This feature imposes its requirements on both experimental equipment and measuring devices, and the experimental technique.

The impossibility of jointly fulfilling the similarities in viscosity and compressibility of air during experimental studies of the aerodynamic interference of propeller engines and an airplane glider, the technical difficulties and the high cost of such studies, all result in a relatively small number of publications devoted to modeling the movement of aircraft with working propellers [30-32]. Investigation of the effect of jets from propellers was previously conducted on large-scale aircraft models in a large AWT (TsAGI T-101). However, such studies have, as a rule, ended after the start of flight tests (due to the complexity of the technical specifications), so the results of experimental studies were late for safety analysis of the initial test flights of the aircraft [30]. This, in turn, actualizes the conduct of experimental studies of the aerodynamic configuration of a wing of small elongation in interaction with propellers, and necessitates the use of numerical methods of aerodynamics.

As it is known, an AWT (Altitude Wind Tunnel) is a high-precision device designed to obtain aerodynamic characteristics with the highest possible reliability. The perfection of the AWT as an instrument depends on the quality of the air flow in the working part and on the accuracy of instruments that measure aerodynamic loads and flow parameters [31, 32]. The AWT of low subsonic velocities T-1 of the Ivan Kozhedub Kharkiv National Air Force University with an open working part is designed to study the aerodynamic characteristics of aircraft models in takeoff, landing and low flight velocities. The reliability of the calculation results is confirmed by comparing the calculation results according to the created methodology with the data of the physical experiments, physical experiments and numerical calculations of other authors and analytical solutions.

To conduct an experiment in a wind tunnel to determine the aerodynamic characteristics of propellers, SDV-1 propeller models of the opposite direction of rotation with a diameter of 0.2 meters were manufactured. Fig. 1 shows the appearance of the models in the working part of the T-1 wind tunnel. The drive is carried out by an electric motor through a gearbox, the torque to ensure rotation of the SDV-1 propeller models is transmitted using a flexible shaft. 
During the weight experiment, the flow velocity in the working part of the wind tunnel varied from 0 to $14 \mathrm{~m} / \mathrm{s}$, the rotor velocity is kept constant and equal to 4740 revolutions per minute. This mode of operation of the propeller approximately corresponds to the Reynolds number $10^{4}$, along the chord of the blade located at $\bar{r}=0.75$. The dependence of the thrust of the SDV-1 propeller model on the flow velocity in the working part of the wind tunnel was listed from known experimental data. The experimental data obtained using the developed experimental technique at two characteristic speeds are shown in Fig. 2.

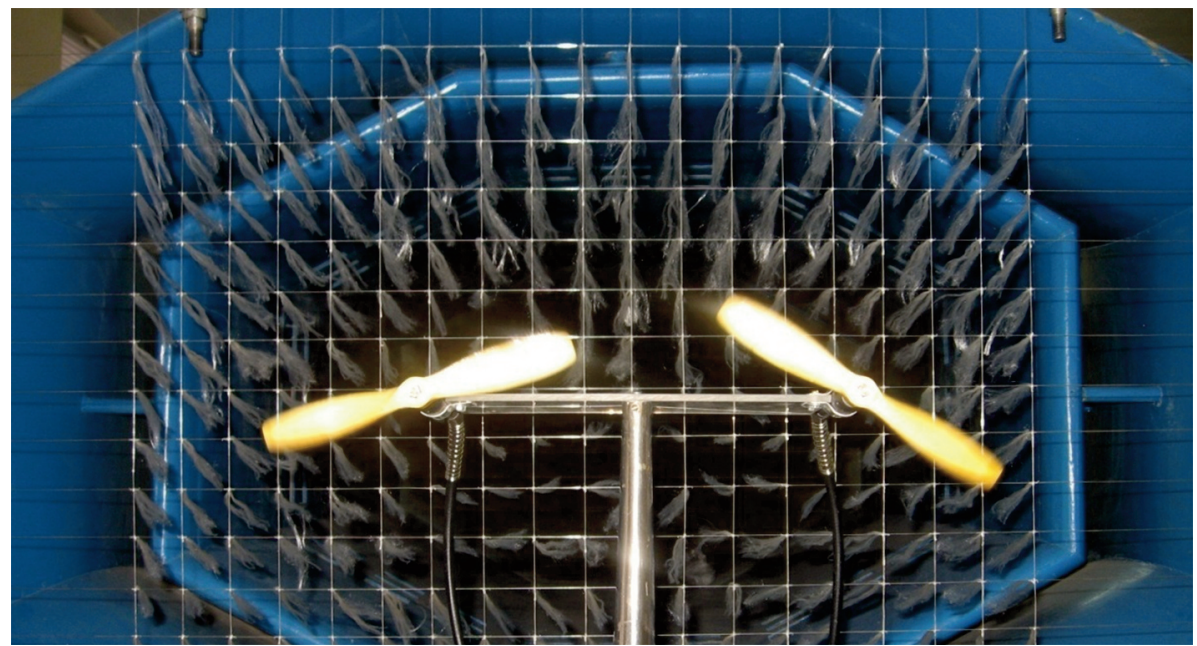

Fig. 1. Photograph of counter-rotating SDV-1 propellers in the wind tunnel T-1.

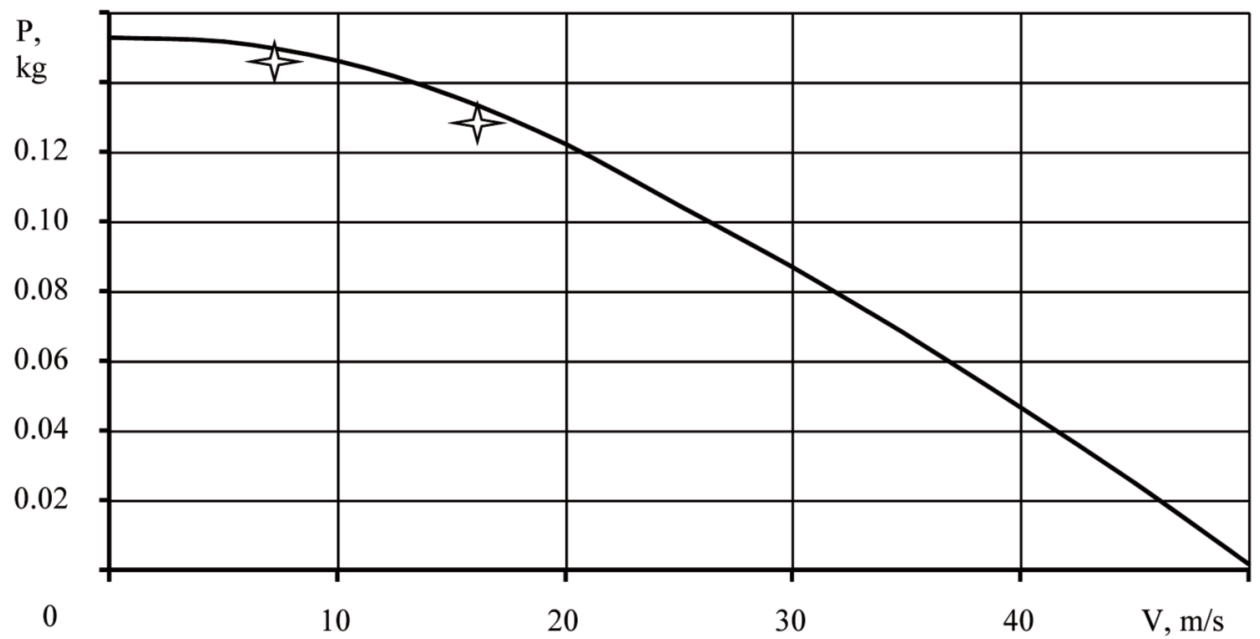

Fig. 2. Comparison of known experimental data [33] of the dependence of the thrust of the SDV-1 propeller model on the flow velocity in the working part of the wind tunnel and the experimental data obtained in our study.

Analysis of the dependence allows us to conclude that the known and obtained experimental data are in satisfactory agreement - attesting to the efficiency of the developed method for determining the aerodynamic characteristics of propellers and the credibility of the results obtained by the method. 
A characteristic feature of the small-elongation wing configuration with propellers is the absence of elements that are not affected by the propellers. This feature makes it difficult to conduct and automate an experiment in a wind tunnel, because there are problems: providing similarity criteria for a working propeller; the difficulty of achieving perfect balancing of propellers causes vibration, the level of which depends on uncontrolled factors; the inability to neglect the presence of the influence of the solid elements of the configuration on the blades of propellers; the difficulty of directly measuring propeller thrust and torque. Thus, the limited possibilities of carrying out a weight experiment in a wind tunnel make it appropriate to combine the use of experimental and numerical methods of aerodynamics.

At Reynolds numbers that correspond to the actual flight of an aircraft with a small-elongation wing with propellers, the viscosity manifests itself in a thin boundary layer, which allows the model of an ideal incompressible medium to be used for calculations. We considered the problem of continuous nonstationary flow around a small-elongation wing in interaction with counter-rotating propellers on the side edges of the wing by subsonic incompressible flow of a non-viscous liquid. The current is considered potential everywhere except the wing surfaces, propellers and the vortex. The meeting places of vortex veils are considered a priori known and fixed.

This work represents a generalization of the work reported in [27]. The developed method of determining the aerodynamic characteristics of the layout of the small-elongation wing with counterrotating propellers at each calculation step requires the condition of "non-permeability" of vortex segments of the veil coming from the propeller blades, panels on which the nacelle surface breaks. Determining the position of the vortex veil behind the small-elongation wing, taking into account the nonlinearity of its spatial position, was carried out using a modified method of discrete vortices (MMDV). Fig. 3 presents the structural and logical scheme of joint solution of the flow problem in the developed method for determining the aerodynamic characteristics.

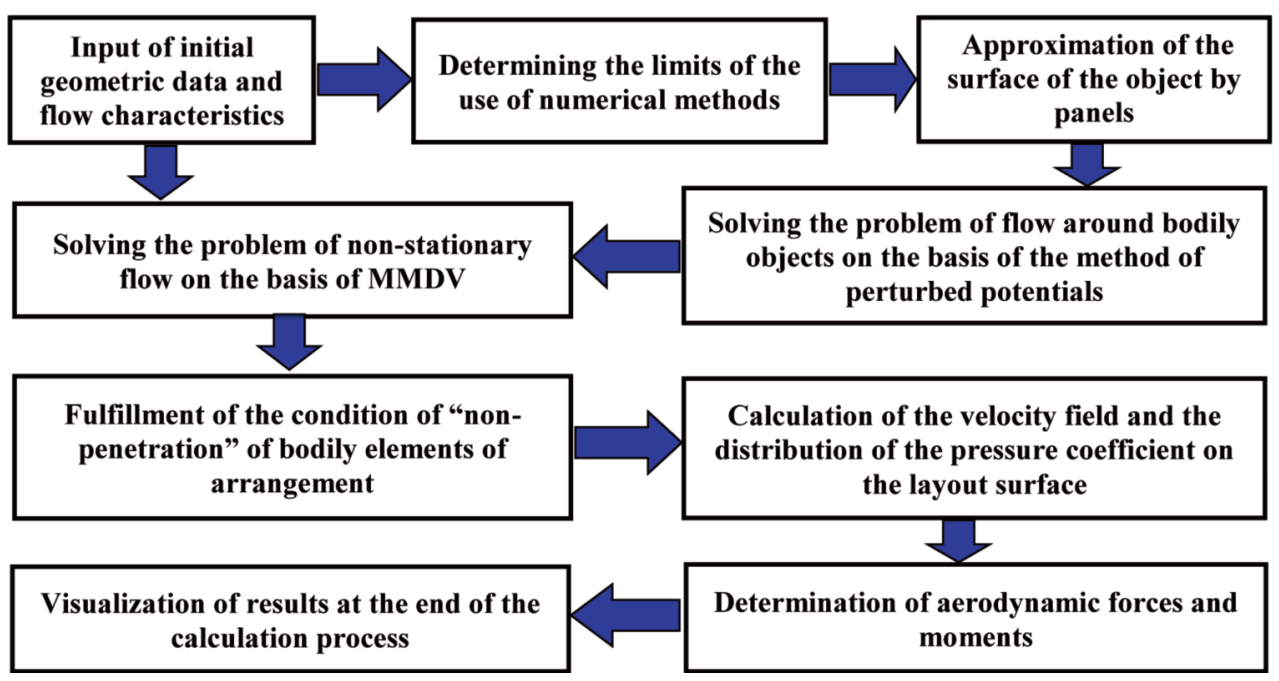

Fig. 3. Structural and logical scheme of joint solution of the flow problem using MMDV and the method of perturbed potentials.

\section{RESEARCH RESULTS}

To determine the influence of the attack angle of the configuration and the operation mode of the propellers on the load-bearing properties of the configuration of a small-elongation wing with counterrotating propellers, we selected the configuration of two four-bladed propellers made up of SDV-1 
propeller blades and a direct wing with lengths of 1, 2, 4 units, panel configuration model is presented in Fig. 4. The elongation of a straight wing means the ratio of the wingspan to its chord.

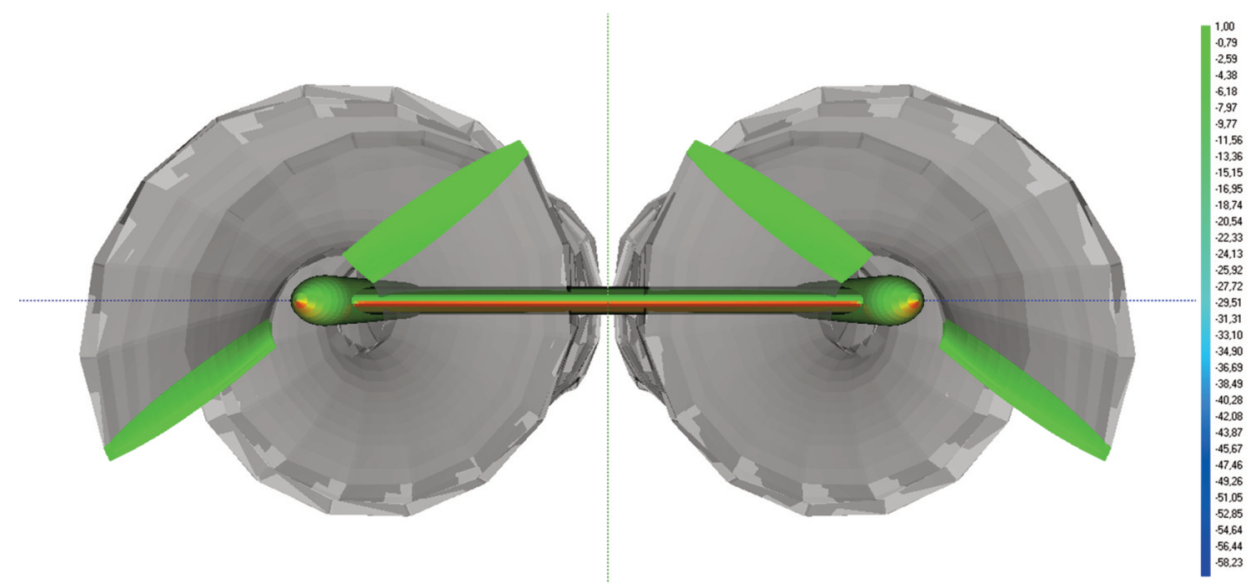

Fig. 4. Panel configuration model of four-blade propellers of opposite rotation, a nacelle and a direct wing.

Fig. 5-6 show the dependences obtained by the developed method for the aerodynamic lift coefficient of a wing with a lengthening of 1 unit on the drag coefficient and the propeller operating mode (load factor on the propeller area B) at the numbers $R e=116500$ and $R e=1165000$ calculated from the wing chord.

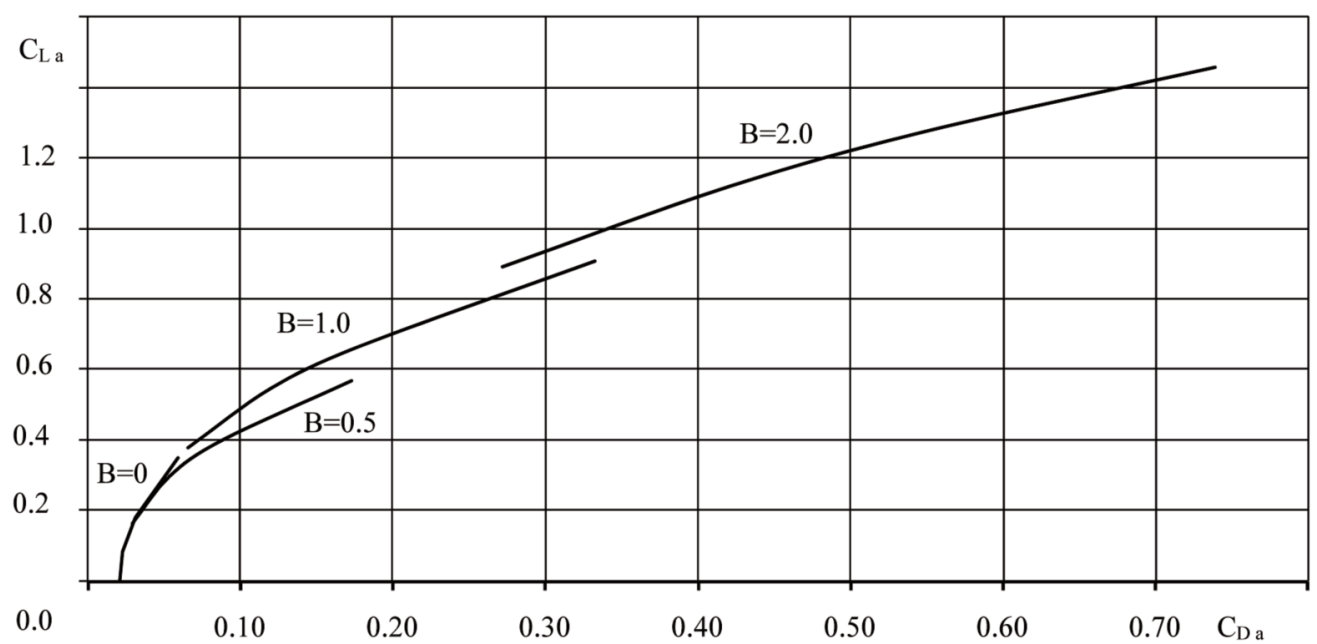

Fig. 5. Dependence of the aerodynamic lift coefficient of the wing on the drag coefficient and propeller operating mode at $\operatorname{Re}=116500$. 


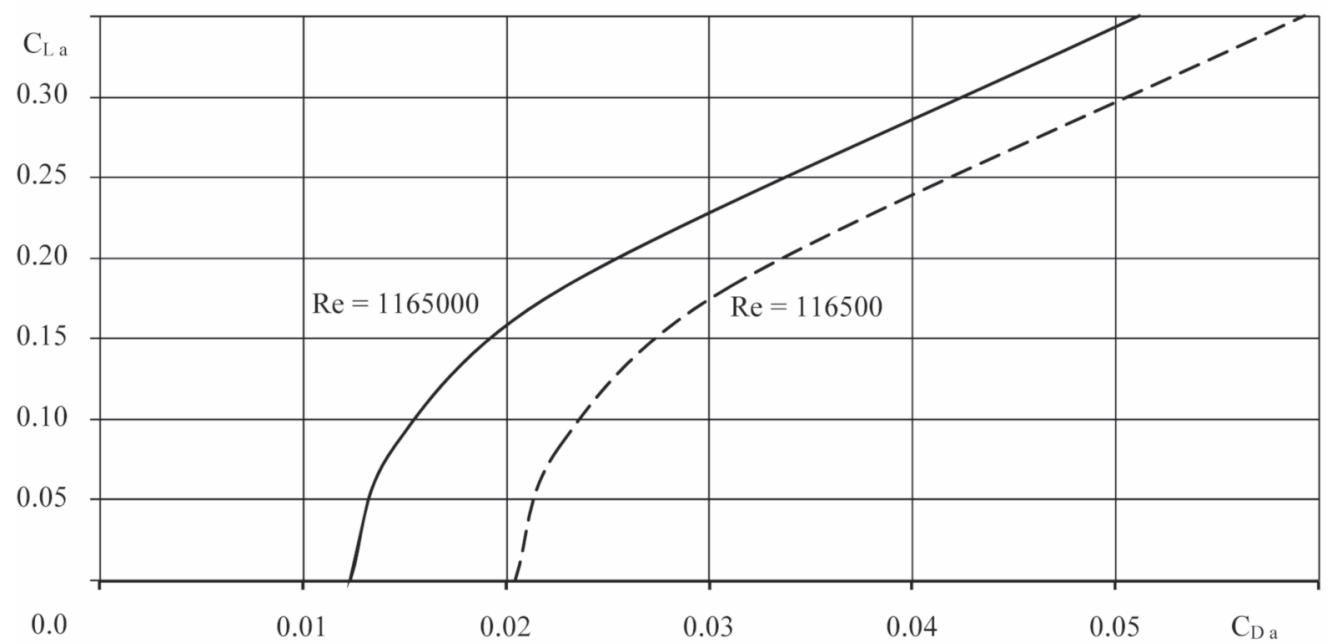

Fig. 6. Dependence of the aerodynamic lift coefficient of an isolated wing on the drag coefficient at $\operatorname{Re}=116500$.

Analysis of the given dependences for wings of other extensions and Re numbers allows us to posit a semi-specific formula for the dependences of the aerodynamic lift coefficient on the attack angle of the configuration and operation mode of propellers:

- to wing elongation in 4 units:

$$
C_{L 0}=\left(-16.95 \cdot \alpha^{2}+1.409 \cdot \alpha+2.167\right) \cdot \square^{2}+\left(-3.153 \cdot \alpha^{2}+4.507 \cdot \alpha+1.812\right) \cdot \square+0.792 \cdot \alpha \text {; }
$$

- to wing elongation in 2 units:

$$
C_{L 0}=(0.249+0.47 \cdot \alpha) \cdot \square+2.51 \cdot \alpha
$$

Thus, we established dependences of the aerodynamic characteristics of the small-elongation wing configuration with counter-rotating propellers on the geometric and kinematic parameters of the configuration for other extensions and constrictions of the wings. These data can serve as the basis for the development of recommendations for the selection of sensible geometric parameters of the aerodynamic configuration of a small-elongation wing with counter-rotating propellers.

\section{DISCUSSION OF THE RESULTS}

The high intensity of secondary vortices is known to affect the vibrations of the entire "gear-propeller" system, causing high stresses in the prop bearings. Therefore, innovative technologies for surface treatment of parts need to be used to increase reliability, resource indicators and operational manufacturability. It is expected that the project goal will be achieved by optimizing the design of the propeller blade supports, the mechanism of the variable pitch propeller, propeller control system. In addition, it is planned to use high-strength materials to support the propeller blades and the control mechanism, to introduce advanced technologies for mechanical and heat treatment, and also to strengthen parts by the AVINIT $\mathrm{N}$ method.

The initial data for the development of the propeller regulator is the shaft rotation frequency, the maximum values of the structural vibrations according to the results of calculating the change in the velocity field, and the critical loads on the prop bearings at maximum engine operating conditions. We anticipate the use of high-strength materials for supporting the propeller blades and the control 
mechanism, the introduction of advanced technologies for mechanical and heat treatment, as well as hardening of parts by the method of surface plastic deformation. Taking into account the intensity of interaction of the high-velocity air flow and the design of the propeller, we also assume the use of:

- a two-channel propeller control system;

- an electronic unit to provide control of the angle of installation of the propeller blades according to the given law in the forward and reverse thrust modes;

- an angle sensor for installing the propeller blades to provide control of the installation angle of the propeller blades by an electronic controller in forward and reverse thrust modes;

- a hydromechanical regulator to ensure the execution of electronic controller commands and maintain a constant rotor velocity in case of failure of the electronic unit (a redundant automatic propeller control system);

- electric driven vane pumps to ensure feathering of the propeller blades by command of the electronic unit or by command from the cockpit.

\section{CONCLUSIONS}

Through a comprehensive theoretical and experimental study, we established the dependences of the aerodynamic characteristics of the UAV fighter composition, namely small-elongation wings with counter-rotating propellers, on the geometric and kinematic parameters of the configuration. Such dependencies are important when designing unmanned vehicles. We developed and presented a theoretical and experimental technique for determining the aerodynamic characteristics of a small-elongation wing assembly with counter-rotating propellers, which uses a combination of experimental aerodynamic methods (to determine the boundaries of using numerical methods and verification of data from numerical experiments) and numerical aerodynamic methods (for parametric studies). The reliability of the recommendations and conclusions is confirmed by the correct use of theoretical methods, by the consistency of the theoretical positions of the obtained experimental data, and by experimental data of other authors. The developed methodology is the basis for obtaining information on the validity of recommendations with the aim of improving the flight performance of UAV assemblies, providing baseline data for the development of a propeller regulator.

\section{REFERENCES}

[1] Sagalovich, A.V., Kononikhin, A.V., Popov, V.V., Dudnik, S.F., Sagalovich, V.V., 2011, "Eksperimental'nyye issledovaniya pokrytiy tipa Avinit" [Experimental studies of Avinit type coatings], Aviacionno-Kosmicheskaya Tekhnika i Tekhnologiya, 3, pp. 5-15.

http://nbuv.gov.ua/UJRN/aktit 201133.

[2] Sagalovich, O.V., Kononikhin O.V., V.V. Popov, 2010, "Ustanovka Avinit dlya naneseniya mnogoslojnyh funkcional'nyh pokrytij" [Avinit installation for application of multilayer functional coverings], Physical Surface Engineering, 8, pp. 336-347. http://dspace.nbuv.gov.ua/handle/123456789/98914.

[3] Sagalovich, A.V., Kononikhin, A.V., Popov, V.V., 2011, "Issledovanie tribologicheskih harakteristik mnogoslojnyh pokrytij MO-S, poluchennyh gazofaznym metodom $s$ ispol'zovaniem metalloorganicheskih soedinenij" [Study of the multilayer MO-C coatings tribological characteristics obtained by the gas-phase method using organometallic compounds], HNADU Bulletin, 54, pp. 44-51.

[4] Fetisov, V.S., Neugodnikova, L.M., Adamovskii, V.V., Krasnoperov R.A., 2014, Bespilotnaya aviaciya: terminologiya, klassifikaciya, sovremennoe sostoyanie [Unmanned aircraft: terminology, classification, current state], Ufa, FOTON. 
[5] Bashinskij, V.G., Bzot, V.B., Zhilin, E.I., Katunin, A.N., Leont'ev, A.B., Ryb'yak, A.S., Ukrainec, E.A., Hrapchinskij, V.O., Hudov G.V., 2014, Malogabaritnye bespilotnye aviacionnye kompleksy (monografiya) [Small-sized unmanned aerial systems (monograph)]. Zaporizhzhia, "JSC Motor Sich”, p. 262. http://www.hups.mil.gov.ua/periodic-app/monograph/2014/85.

[6] Rankine, W.J., 1865, On the Mechanical Principles of the Action of Propellers, 4th ed., Transactions of the Institute of Naval Architects, pp. 13-39. https://www.worldcat.org/title/on-the-mechanicalprinciples-of-the-action-of-propellers/oclc/40237703.

[7] Gubskij, V.V. 2017, Interferenciya vozdushnyh vintov s elementami planera i mekhanizaciej kryla legkogo transportnogo samoleta na rezhimah vzleta i posadki [Interference of propellers with airframe elements and wing mechanization of a light transport aircraft in take-off and landing modes], Ph.D. thesis, TsAGI, Zhukovsky, Chap. 5, pp. 82-96. https://www.dissercat.com/content/interferentsiyavozdushnykh-vintov-s-elementami-planera-i-mekhanizatsiei-kryla-legkogo-trans.

[8] Wood, D.H, Bioletti, C., 1934, Tests of Nacelle-Propeller Combinations in Various Positions with Reference to Wings. Part VI. Wings and Nacelles with Pusher Propeller. NACA TR-507, pp. 619-649.

[9] Borin, A.A., 1970, Vliyanie obduvki chastej samoleta struej ot vinta na harakteristiki vzleta $i$ razbega [Influence of propeller jet blowing of aircraft parts on take-off and take-off run characteristics], TsAGI, Zhukovsky, 1278, p. 16.

[10] Zolotko, E.M., 1984, Pod"emnaya sila kryla, obduvaemogo struej ot vintov, pri izmenenii koefficienta nagruzki na ometaemuyu vintom ploshchad' ot 0 do $\infty$ [The lifting force of the wing blown by the jet from the propellers, when the load factor on the propeller-swept area changes from 0 ti $\infty$ ], TsAGI, Zhukovsky, 2235, pp. 3-10.

[11] Naumov, S.Y., Pustovoitov, V.P., Rudenia, V.I., 1971, Metodika rascheta vliyaniya vozdushnyh vintov na aerodinamicheskie harakteristiki samoleta [Method for calculating the propellers effect on the aerodynamic characteristics of an aircraft], TsAGI, Zhukovsky, 1312, p. 40.

[12] Ukrainets, E.A., 1998, Aerodinamicheskie harakteristiki nesushchih sistem letatel'nyh apparatov s soosnymi vintovymi dvizhitelyami [Aerodynamic characteristics of the aircraft bearing systems with coaxial propellers] Ph.D. thesis, National Aviation University, Kyiv, p. 148.

http://lawdiss.org.ua/ard/99ueosgr.shtml.

[13] Myrhorod, Y.I., Kalkamanov, S.A., Ukrainets, E.A., 1998, “Doslidzhennia vplyvu kilkosti lopatei na stupin nestatsionarnosti strumenia za hvyntovym rushiiem" [Investigation of the influence of the number of blades on the degree of non-stationarity of the jet on the propeller], Zbirnyk. nauk. prats Kharkivskogo instituty liotchkiv, 2, pp. 44-47.

[14] Gotsak, V.V., Ukrainets, E.A., 2003, "Metodyka rozrakhunku aerodynamichnykh kharakterystyk skladnykh komponuvan" [Method of calculating the aerodynamic characteristics of complex configurations], Zbirnyk. nauk. prats Kharkivskogo instituty liotchkiv, 1(9), pp. 11-16.

[15] Deryshev, S.G., 2000, Aerodinamicheskaya interferenciya vozdushnyh vintov $i$ planera dvuhdvigatel'nogo samoleta [Aerodynamic interference of propellers and glider of a twin-engine aircraft], Ph.D. thesis, Siberian Research Institute of Aviation, p. 171.

https://www.dissercat.com/content/aerodinamicheskaya-interferentsiya-vozdushnykh-vintov-iplanera-dvukhdvigatelnogo-samoleta.

[16] Lemko, O.L., 2002, "Letayushchie kryl'ya" [Flying wings - History and Possible Ways of Development], NTs VVTs VCU, p. 91.

https://ela.kpi.ua/bitstream/123456789/7834/1/pap_14.pdf.

[17] Lukov, G.I., Kiseleva, A.M., 1987, "Issledovanie pri malyh skorostyah fizicheskoj kartiny raspredeleniya zavihrennosti potoka okolo modelej samoleta skhem 'beskhvostka' i 'utka' s krylom malogo udlineniya" [Physical pattern investigation at low speeds of the distribution of flow vorticity near the aircraft models of the "tailless" and "duck" schemes with a wing of small elongation], TsAGI, Zhukovsky, 2341, pp. 3-29. 
[18] Degani, D., Mareus, S.W., 1997, “Thin vs full Navier-Stokes computation for high-angle-of-attack aerodynamics" AIAA Journal, 35(3), pp. 565-567. https://link.springer.com/chapter/10.1007/9781-4612-2824-0 9

[19] Koval, M.O., Kalkamanov, S.A., Chygryn, R.M., 2004, "Aerodinamichni komponovki perspektivnih litakiv vertikal'nogo zl'otu ta posadki” [Aerodynamic layouts of promising vertical takeoff and landing aircraft], Issues of design and manufacture of aircraft structures, National Aerospace University "Kharkiv Aviation Institute", 36(1), pp. 37-42.

[20] Kalkamanov, S.A., Chygryn, R.M., 2003, "Metodika rascheta obtekaniya diskoobraznogo kryla potokom ideal'noj zhidkosti" [Method for calculating the flow of an ideal fluid around a diskshaped wing], Open information and computer integrated technologies, National Aerospace University "Kharkiv Aviation Institute", 21, pp. 63-66.

[21] Kornienko, A.P., Ukrainets, E.O., Mokry, Yu.V., 2004, "Metodyka rozrakhunku aerodynamichnykh kharakterystyk systemy arochne krylo - shtovkhaiuchyi hvynt" [Method of calculating the aerodynamic characteristics of the system arched wing - pushing propeller], Issues of design and manufacture of aircraft structures, National Aerospace University "Kharkiv Aviation Institute", 39(4), pp. 71-79.

[22] Kornienko, A.P., 2005, “Eksperimental'nye issledovaniya haraktera obtekaniya izolirovannyh pryamogo i arochnogo kryl'ev" [Experimental studies of the nature of the flow of isolated straight and arched wings], Issues of design and manufacture of aircraft structures, National Aerospace University "Kharkiv Aviation Institute", 42(3), pp. 118-123.

[23] Kornienko, A.P., 2005 "Eksperimental'nye issledovaniya kartiny raspredeleniya davleniya po poverhnosti arochnogo kryla v sisteme 'arochnoe krylo - tolkayushchij vozdushnyj vint" [Experimental studies of the pattern of pressure distribution on the surface of the arched wing in the system "arched wing - pushing air screw"] Zbirnyk naukovykh prats KhUPS, 5(5), pp. 10-13.

[24] Kornienko, A.P., Leontiev, A.B, Ukrainets, E. A., 2006, “Ocenka vliyaniya otnositel'nogo polozheniya vozdushnogo vinta na aerodinamicheskie harakteristiki kombinacii "arochnoe krylo vozdushnyj vint"' [Evaluation of the influence of the relative position of the propeller on the aerodynamic characteristics of the combination "arched wing - propeller"], Information Processing Systems, Kharkiv. KhUPS, 4(53), pp. 87-94.

[25] Kydushun, I.V., 2001, "Raritety amerikanskoj aviacii" [Rarities of American aviation], Moscow, ACT, pp. 112-147. http://loveread.ec/read book.php?id=77533\&p=22.

[26] Ruzhitsky, E.I., 2000, "Amerikanskie samolety vertikal'nogo vzleta" [American vertical takeoff aircraft], Moscow, Astrel ACT. pp. 74-114.

https://royallib.com/book/rugitskiy evgeniy/amerikanskie samoleti vertikalnogo vzleta.html

[27] Gotsak, V.V., 2005, "Syntez metodu zburenykh potentsialiv ta metodu dyskretnykh vykhoriv dlia rozrakhunku neliniinykh nestatsionarnykh aerodynamichnykh kharakterystyk litakiv" [Synthesis of the perturbed potential method and the discrete vortex method for calculating nonlinear nonstationary aerodynamic characteristics of aircraft], Zbirnyk naukovykh prats KhUPS, Kharkiv, 3(3), pp. 29-31.

[28] Radtsig, A.N., 2004, Eksperimental'naya gidroaeromekhanika [Experimental hydroaeromechanics], Moscow, MAI, p. 296.

[29] Miranda, L.R. and Brennan, J.E., 1986, "Aerodynamic effects of wing tip mounted propellers and turbines", AIAA 86(1802), pp. 221-228.

[30] Vasin, I. S., 2010, "Issledovanie vliyaniya struj ot vozdushnyh vintov na aerodinamicheskie harakteristiki samoleta" [Study of the influence of jets from propellers on the aerodynamic characteristics of an aircraft], Scientific Bulletin MGTU GA, 151, pp. 39-43.

https://cyberleninka.ru/article/n/issledovanie-vliyaniya-struy-ot-vozdushnyh-vintov-naaerodinamicheskie-harakteristiki-samoleta/viewer. 
[31] Radtsig, A.N., Semenchikov, N.V., 1992, Model'nyj eksperiment v aerodinamicheskih trubah [Model experiment in wind tunnels], Moscow, MAI, p. 65.

[32] Zhuravlev, V.N., 2016, Aerodinamicheskij kompleks HAI - osnovnye etapy razvitiya i nauchnoj deyatel'nosti 1950-2010 [Aerodynamic complex KhAI - the main stages of development and scientific activity 1950-2010], National Aerospace University “Kharkiv Aviation Institute”, p. 156. http://aoleynik.info/aerodinamicheskij-kompleks-xai/.

[33] Kravets, A.S., 1941, Harakteristiki vozdushnyh vintov [Propeller specifications], Moscow, State Publishing House of the Defense Industry, pp. 148-151.

\title{
METODA WYZNACZENIA \\ CHARAKTERYSTYK AERODYNAMICZNYCH MYŚLIWCA ANTY-DRONOWEGO Z NAPĘDEM ŚMIGŁOWYM PODCZAS PROJEKTOWANIA ŚMIGIEE
}

\begin{abstract}
Abstrakt
W artykule podjęto problem wyznaczania charakterystyk aerodynamicznych podczas projektowania śmigieł do skrzydeł małych bezzałogowych statków powietrznych (UAV). Omówiono metodykę eksperymentalnych badań nad różnymi konfiguracjami statków ze śmigłami w tunelu aerodynamicznym. Wykazano, że konfiguracje skrzydła o małym wydłużeniu ze śmigłami charakteryzują się brakiem elementów, na które śmigła nie mają wpływu. Cecha ta utrudnia realizację i automatyzację eksperymentów $\mathrm{w}$ tunelu aerodynamicznym, powodując problemy z zapewnieniem podobnych warunków do pracy śmigła, trudność w uzyskaniu idealnego wyważenia dla śmigieł z napędem stałym, drgania, których intensywność zależy od niekontrolowanych czynników, niemożność pominięcia obecności elementów nadwozia oddziałujących na łopaty śmigieł oraz trudność bezpośredniego pomiaru ciągu i momentu obrotowego śmigła. Przedstawiona metodyka polega na zintegrowanym wykorzystaniu metod eksperymentalnych i numerycznych w celu wyeliminowania trudności w przeprowadzaniu eksperymentów w tunelu aerodynamicznym. Takie podejście pozwala na połączenie wysokiej wiarygodności danych doświadczalnych w badaniu fizycznej istoty zjawisk z wysoką efektywnością i dokładnością wyznaczania charakterystyk aerodynamicznych metodami numerycznymi. Ustalono zależności charakterystyk aerodynamicznych konfiguracji skrzydła o małym wydłużeniu ze śmigłami przeciwbieżnymi od parametrów geometrycznych i kinematycznych konfiguracji dla innych wydłużeń i zwężeń skrzydeł. Wyniki te mogą stanowić podstawę do opracowania zaleceń dotyczących doboru racjonalnych parametrów geometrycznych konfiguracji aerodynamicznej skrzydła o małym wydłużeniu ze śmigłami przeciwbieżnymi.
\end{abstract}

Słowa kluczowe: bezzałogowy statek powietrzny, myśliwiec, charakterystyka aerodynamiczna, konfiguracja aerodynamiczna, śmigło, regulator śmigła. 